\title{
The subject of exemption: through discourses of normalization and individualization in Denmark
}

\author{
Bjørn Hamre* \\ Danish School of Education \\ Aarhus University \\ E-Mail: biha@edu.au.dk \\ *corresponding author

\section{Tine Fristrup} \\ Danish School of Education \\ Aarhus University \\ E-Mail: tifr@edu.au.dk

\section{Gerd Christensen} \\ Department of Media, Cognition and Communication \\ Copenhagen University \\ E-mail: gerd@hum.ku.dk
}

\begin{abstract}
This article examines the constructions of the deviant subject in Danish Foucauldian educational research. Following the work of Foucault, we argue that the deviant subject, on the one hand, could be considered as a subject of exemption. In this case, exemption is deduced from Foucault's understanding of the relation between normality and deviancy. On the other hand, an examination of Danish Foucauldian disability research shows that this conception of 'the deviant subject' has changed over time. Hence, the present expectations of 'the disabled' are - more or less - influenced by contemporary discourses of general education. Thus, this article argues that Foucauldian disability studies could benefit from taking into account Foucauldian research in the field of general education. Until recently, the two research fields have been mutually isolated.
\end{abstract}

Keywords: normality, deviancy, normalization, disability studies, the subject of exemption, general education, Denmark 


\section{Introduction}

The distinction between normality and deviancy, and therewith exemption, is one of the recurring themes in the French philosopher Michel Foucault's work. According to Foucault, madness is a condition that has changed its image from the medieval period to the Renaissance and modern times, along with the transformation of society. However, a major shift took place in the middle of the seventeenth century: '[...] the world of madness becomes the world of exclusion' (Foucault, 2005, p. 117). This is related to the emergence of institutions solely serving the function of internment. In his archaeological examination, L'histoire de la Folie (Foucault 1961), Foucault explores how the emergence of the asylum tends to position the mad as 'an exemption' from reason and normality.

The important point here is that normality cannot be understood without abnormality and vice versa. They establish, so to speak, each other's constitutive 'outside' (Deleuze, 1986). Thus, the two are dependent on one another. The role of the researcher is, then, to examine the relationship between the two. This is also the case when Foucault shows how disciplinary power constantly reconstructs the relation between normality and deviancy in schools and institutions (Foucault, 1979; 2006).

It is meaningless to reduce Foucault's complex thoughts solely to the deviancy-normality issue, since his writings cover many other themes like disciplinary power, the will to knowledge and truth, the subject, and so forth. As we know, Foucault develops and refines his understanding of normality and deviance throughout his authorship. In light of this, it is striking that Danish Foucauldian educational research has followed two separate tracks: one focusing on special (needs) education, and one focusing on general education. When it comes to discussions of pedagogical practice in schools it is, therefore, manifest that the two tracks or traditions have hardly communicated with one another.

The two traditions can positively influence each other (Hamre, 2012, 2014). Thus, in this article, it is argued that an examination of a possible transgression between the two research areas might lead to new valuable insights into 'the subject of exemption'. This hypothesis entails that studying deviancy and problematic behaviour in schools must include what is regarded as normal behaviour in a given period and institutional setting. This article demonstrates that the very marked delineation between deviancy and normality becomes less clear in present conceptions of 'the subject of exemption'. Thus, the demarcating line between the research field of general education and disability studies cannot be upheld. Issues like diagnosing, classification and stigmatization must include analyses of the constructions of normality in schools.

The methodological approach in the article takes the form of archaeology of knowledge. Hence, this article first presents an introduction to the research field of Danish Foucauldian disability studies; secondly, it examines how studies in governmentality and subjectification in general education can possibly contribute to a contemporary analysis of this subject. Accordingly, this article is positioned within the tradition of critical educational research (see e.g., Masschelein, 2004) and critical disability studies (Allan, 2005; 2008; Tremain, 2005; Slee \& Cook, 1999; Slee, 2011; Baker, 2002; Goodley, 2011; Goodley \& Rapley, 2002/2006). In international Foucauldian critical disability studies, the emphasis is foremost on the problem of inclusion of 'the deviant'; however, this is not explicitly the aim of this article. And though the field has 
an international background, it is important to note that the focus of the present article is on the Danish conditions for research and current issues related to this context.

\section{Danish Foucauldian disability studies on the efforts towards normalization}

Michel Foucault's analysis of the normality-deviancy issue (Foucault, 1962; $2001 ; 2005 ; 2006)$ was introduced in a Danish context in the beginning of the 1970s. The first translated book was Maladie mentale et psychologie (Foucault, 1962), published in Denmark in 1971 as Sindssygdom og psykologi [Mental illness and psychology], and published and revised again in 2005. The French version from 1962 contained a chapter summing up the main points from Folie et Déraison: Histoire de la folie à l'âge classique, which was published and defended by Foucault in 1961. This work was not translated into Danish until 2003, when it was entitled Galskabens historie i den klassiske periode [The history of madness in the classical age], considered to be very close to Foucault's original work. However, the book was also circulated in Denmark in a highly abbreviated Norwegian translation (Foucault, 1973), which did not capture the literary originality in Foucault's language. Survieller et Punir (1975) was translated into Danish as Overvågning og straf [Survelliance and Punish] (Foucault, 2002) but a Norwegian translation had already been published in 1977. Histoire de la sexualité 1. La volonté de savoir (Foucault, 1976) was translated to Danish in 1978 as Seksualitetens historie, 1: Viljen til viden [The history of sexuality, 1: the will to knowledge], and revised and published again in 1994.

Apart from these translations, Danish scholars, primarily with a background in literature studies, philosophy or studies within the history of ideas, presented the normality-deviancy issue and the critique of institutions in a number of introductions to Foucault's thought; some of the most important include: Esbern Krause-Jensen, Viden og magt. Studier i Michel Foucault's institutionskritik ([Knowledge and power: studies in Michel Foucault institutional criticism] 1978); Dag Heede, Det tomme menneske ([The empty human] 1992); and Jens Erik Kristensen, Knut Ove Eliassen and Niels Brügger's anthology of various works by the philosopher, Foucault's masker ([Foucault's masks] 1995). These introductions all appeared in the Danish context before the translations of works such as Folie et Déraison: Histoire de la folie à l'âge classique and Survieller et Punir (translated into Danish in 2003 and 2002).

Only a few Danish researchers within disability studies have carried out research from a Foucauldian perspective. These studies lie mostly within the frame of the history of disability, as a way of questioning or problematizing the research undertaken in the field of special-needs education - a field of research which was and remains primarily the domain of psychologists and educational psychologists. The most prominent researcher in the Danish history of disability has been the historian Birgit Kirkebæk, who has conducted several research projects, all within a Foucauldian framework (Kirkebæk, $1985 ; 1993 ; 1997 / 1998 ; 2001 ; 2004 ; 2007 ; 2009 ; 2010)$. Edith Mandrup Rønn has also conducted research within the field of disability history, but with an ethnological approach to her work on the living conditions of disabled people throughout history (Rønn, 1996). Another prominent researcher is Jesper Holst, who has used Foucault's framework in order to question the living conditions of institutionalized disabled people. Holst has a background within the research field of social pedagogy and uses the Foucauldian approach to 
problematize institutionalization as processes of normalization throughout history (Holst, 1977; 1993; 1998; Holst et al., 2000). Finally, Frank Bylov (2006; 2010) has made a major contribution to understanding the development of empowerment movements among people with intellectual disabilities with inspiration from Kirkebæk's interpretations of the Foucauldian framework. Bylov's research focuses on how pedagogical strategies have encouraged disabled people to organize in different movements as counterdiscourses to the dominant medicalization of disabled people.

One could say that the contributions from these four Danish researchers belongs to the first generation of Danish Foucauldian research on disability. This research focuses especially on the efforts towards normalization in the 1950s closely related to the pioneering work conducted by the then Danish Head of Welfare, Niels Erik Bank-Mikkelsen. His efforts were directed against the eugenic discourse and involved a critique of how Danish society treated disabled people; he proclaimed that 'we' could and should do better, meaning that 'we' as a society could give disabled people a better life than the ideal 'normal life' (Bank-Mikkelsen, 1971).

This article interprets the first generation of Danish Foucauldian disability research as a departure from a normative emancipatory project in the wake of the social political agenda of the 1930s. It installed a process of normalization as a prophylactic approach to the improvement of the Danish population, underlining the unavoidable humanism in the wake of the 1948 Universal Declaration of Humans Rights (Kristensen \& Schmidt, 1989). Bank-Mikkelsen introduced the concept of 'normalization' as a specific 'deinstitutionalization' of disabled people with regard to a 'visibility' and 'equality' approach to improve the living conditions of disabled people in Denmark. This historical concept is significantly different from Foucault's analytical use of normalization in contrast to deviation. It was seen as an effort to install a counter-discourse to the dominant eugenic and medicalized approach to disability. According to a report from the United Nations on human rights and disability, there has been a dramatic shift in perspective towards disabled people over the past two decades in favour of a human-rights perspective on disability, which entails moving away from viewing people with disabilities as problems towards viewing them as holders of rights; the debate about the rights of disabled people is, therefore, connected to a wider debate about the place of difference in society (Quinn \& Degener, 2002).

The counter-discourse was made possible in relation to the aforementioned 1948 Universal Declaration of Human Rights (Bank-Mikkelsen, 1971). In Article One of the declaration, there is a notion of 'reason and conscience', which has been used to question the lives of disabled people during the period from the 1880s to the 1950s (UN, 1949). Earlier, from about 1855 until the 1880 s, the view of disabled people was more akin to an optimistic belief in a possible cure for disabilities (Bank-Mikkelsen, 1971; Kirkebæk, 2010). The shift in the 1880s towards a protectionist approach resulted in a classification of disabled people into those who could benefit from treatment or interventions and those who could not (Bank-Mikkelsen, 1971; Kirkebæk, 2010; Rønn, 1996).

Those disabled people who were regarded as being beyond medical and educational reach were excluded, classified as incurable and uneducable, and placed in asylums or prisons, just like criminals (Kirkebæk, 2010). This past classification of disabled people as uneducable is reversed in current Danish society, because disabled people have become 'educable subjects' due to a general shift to a human-rights perspective and a specific approach to The 
United Nations Educational, Scientific and Cultural Organization (UNESCO) Salamanca Statement from 1994 and the UN Convention on the Rights of Persons with Disabilities from 2006. When disabled people become subjects they experience the different subjectifications made available in contemporary society; in this case, the processes of subjectification follow the education or learning agenda from the 1990s, a point to which this article will return. In order to demonstrate how this change is made possible, the article follows the construction of different discourses in Danish Foucauldian disability studies.

Danish social political discourse from the 1930s developed during the period from the 1950s to the 1970s into a strong critique of the institutionalization of disabled people, which had been going on since the 1880s (Holst, 1993; Kirkebæk, 1993). The pioneering work of Bank-Mikkelsen on trying to broaden the conceptualization of 'the normal person' followed the human-rights declaration and the legal changes occurring in 1959. An Act known as 'Åndssvageloven', (i.e., an Act directed towards those regarded as feebleminded) made it possible to talk differently about the lives of disabled people according to the discourse of normalization that followed the passing of the law. In general terms, it meant that the efforts of medical categorization were questioned in the normalization efforts emphasizing both deinstitutionalization and decategorization (Rydberg, 2006).

Since the 1970s, Denmark has witnessed an approach to the lives of disabled people that is focused on education, training, and treatment, albeit with an understanding of disabled people as objects and not yet as subjects (Quinn \& Degener, 2002). The discourse on education, training, and treatment follows two different tracks, which can be seen as relating to disabled people as objects in contrast to disabled people as subjects (Quinn \& Degener, 2002). The 'objectifying' track is constituted in a psycho-medical discourse and aims at training and adaptation (Kirkebæk, 2010). The other, 'subjectifying' track follows a social discourse focusing on social relations and quality of life (Kirkebæk, 2010).

It is possible to see the development of these two tracks in disability history as two different approaches to the past efforts towards normalization underlying the shift to a human-rights perspective over the past two decades, best exemplified by the United Nations Standard Rules on the Equalization of Opportunities for People with Disabilities, adopted by the General Assembly in resolution 48/96 of 20th December 1993 (Quinn \& Degener, 2002). This shift in perspective from the 1990s has made possible the present efforts towards individualization in the contemporary Danish approach to the lives of disabled people as individuals (subjects), and in relation to Danish educational research concerning the construction of the individual as the educable subject' (Rydberg, 2006; Hamre, 2012; 2014; Drejer, 2012).

In order to understand how an individual is constructed as a deviant subject, it is necessary to consider and analyse the efforts made in the 1950s to introduce the concept of normalization. According to Holst (1993), the efforts towards normalization have made the lives of contemporary disabled people possible as an articulation of social barriers, whether this is related to environmental issues or oriented towards the use of language. The efforts towards normalization were grounded in a discourse on the integration of disabled people into society, departing from the UN Standard Rules on the Equalization of Opportunities for Persons with Disabilities from 1993.

Within a Foucauldian framework, it is possible to understand 'normalization' relationally, historically, practically, and critically. This can contribute to the 
understanding of what constitutes 'the deviant subject' as an object, when it is elaborated in a psycho-medical discourse and ordered as a deficit model with a focus on the bodily embedded deficits articulated as 'impairments'. In the critique of the objectifying and non-social approach to disability as impairments, the individual deficit has been challenged by the social approach to disability. This was done in order to question the ways in which society governs the construction of deviation and 'deficient' objects. In order to debunk the dominant medicalization efforts in Danish society, the notion of object and subject constellations in a human-rights perspective can be interpreted as a normalizing humanization initiative in regard to the processes of deinstitutionalization and decategorization (Rydberg, 2006). This debunking is based on a subject-object dialectic and grounded in an essentialist view, different from Foucault's anti-essentialist approach; further, in this case, the 'debunking' is shaped as a normative approach, and the self-evident understanding of the normalization (humanization) efforts as creating better and more humane lives for disabled people than medicalization and diagnostic efforts have done.

\section{The pedagogical turn}

Bylov's (2006; 2010) work elaborated on the development of a pedagogical turn in the approach to the lives of disabled people in regard to the efforts towards normalization, which resulted in the Act known as 'Andssvageloven' and disabled people's right to education (Rydberg, 2006). The efforts at medicalization were challenged and questioned in the 1970s as the need for deinstitutionalization and decategorization, and a general humanization of disabled people was articulated as an issue of social integration (Rydberg, 2006). In the 1990s, the integrative approach to social cohesion was questioned and social inclusion became the new framework of an inclusive approach to advance social cohesion in Danish society, which later developed into 'inclusive education' and a problematization of the limits in the integrative approach (Holst et al. 2000). Both of the questions, or problematizations, focused on social cohesion as a necessary approach to maintaining sustainability in Danish society, and were elaborated in regard to the generalization of education as a human right that followed the UN Standard Rules from 1993 that included disabled people as 'educable citizens' (Rydberg, 2006; Kristensen, 2012).

But while functioning as a social and political drive to empower disabled people to live independent lives, the pedagogical (integrative) discourse became a social barrier to the emancipation of disabled people (Bylov, 2010). 'The disabled' became, in a Foucauldian sense, subject to a new discursive construction of 'people with special needs', and the need for pedagogical and therapeutic approaches articulated a 'lifelong special-education configuration' of their lives. The issues of integration were problematized in the dualistic objectifying and subjectifying approaches to the construction of 'the subject of deviation' as 'the object of special needs'.

The efforts towards normalization replayed the dualism between the individual and the social because the efforts to integrate constituted the processes of normalization in favour of society: the individual had to adapt to society and not vice versa. This can be interpreted as an individual deficit and socialbarrier approach that constitutes 'the deviation subject' as a 'subject of exemption'. 'The disabled people' have become normalized; however, in an integrative approach they are constructed as subjects of exemption that can be managed through the pedagogical approach to their special needs 
because of the objectifying approach and the tendency to perceive people with special needs as problems (Allan, 2008).

In Danish Foucauldian studies of disability, the construction of the deviant subject is constituted as a possible consequence of the project of modernization from the 1800s eugenic discourse and further into the normalization efforts of the early 1930s and late 1950s in the development of a social and political discourse. The humanization efforts in the social and political discourse elaborated a more explicit individualizing approach in the 1980s and 1990s with regard to the shift into a human-rights perspective on the social and political agenda in order to pursue empowerment strategies in the elaborated pedagogical discourses on social inclusion (Rydberg, 2006; Bylov, 2010; Kirkebæk, 2010; Hamre, 2012; 2014; Drejer, 2012). When looking into the literature that elaborates the pedagogical discourse on 'inclusive education' as a problematization of the approach of 'special-needs education' to the construction of the subject of exemption, an explicit Foucauldian approach to the problematization is missing.

The efforts towards normalization in the era of integration have been challenged by changes in an increasingly individualized society. Following an (inclusive) agenda on 'education and learning' as the 'best' way to obtain social cohesion in an individualized society (Kristensen, 2012), the efforts for greater normalization and integration have become challenged by the efforts for further individualization and inclusion. In the literature on 'inclusive education', researchers point to a necessary shift in the approach to pedagogy and education, which transgress 'the special education' into 'a general education' (Holst et al., 2000). Drawing on the analysis outlined above, we argue here that the past normalization (with a focus on integration) efforts (emphasizing training and adaption) have become the present individualization (with a focus on inclusion) efforts (emphasizing social relations and quality of life): both disabled and non-disabled people have become 'equally' individualized as educable subjects with individual (special) approaches to learning in current Danish 'learning' society.

\section{Individualization in Danish Foucauldian educational research}

The view of deviancy has changed over time; in a (post-) modern Western society, everybody is considered as an individual, and thus as something 'special'; further, in a 'learning society', everybody is (or must be) potentially educable. Concerning research, it therefore seems reasonable that disability studies embraces or at least looks a little further into the research field of the construction of normality in education. Here, the inspiration from Foucault has had a major impact in Denmark in recent decades.

Danish researchers have conducted Foucauldian analyses of gender (Søndergaard, 2000); gender, ethnicity, and school life (Staunæs, 2002; Kofoed, 2003; Helms \& Krøjer, 2011); parental involvement (Knudsen, 2010); school architecture (Juelskjær, 2007); and student project groups (Christensen, 2013). The assumption made by all these studies is that the subject for education is not a static phenomenon, but (to a varying extent) an effect of the present discourse. Accordingly, the aim of the Foucauldian research is (philosophical) critique: to question ideas that are taken for granted in our culture. Questioning the truisms of pedagogics and education inevitably leads to questioning 'what we (as educators and researchers) are doing while we are doing it' (Allan, 2005, p. 291). This is also the case in the educational 
research that focuses on analyses of the discourse of education (e.g., Hamre, 2014; Krejsler, 2002; Krejsler, (ed.) 2004; Drejer, 2012; Christensen, 2008). From different angles, these studies are all concerned with the construction of 'the normal child' as the subject of normalization. Thus, they may be considered as resources for further development of the field of disability studies.

Danish Foucauldian educational research can roughly be divided into two traditions: 1) a tradition that primarily focuses on the perspectives of power/knowledge (pastoral, disciplinary, bio-power) and the construction of the human subject; and 2) a tradition that focuses primarily on governmentality. The former focuses on the micro-genetics of the construction of the individual as a subject, whereas the studies of governmentality concern the micro- and macro-genetics of government in the (post-) modern state (Senellart, 2004; Hamre, 2012; 2014). While the former can be regarded as belonging to the discipline of social psychology, the latter can be regarded as belonging to the social sciences. Thus, governmentality is Foucault's terminology for the internalization of political control mechanisms that make the individual 'government-able' (Foucault, 1991; Senellart, 2004). However, in practice, the studies in both areas are quite diverse and the two traditions are rather intertwined and overlapping. Hence, the division outlined below is not fixed and is indeed difficult to uphold.

\section{The construction of 'the educable subject'}

Foucauldian studies within the field of social psychology are based on the concept of power/knowledge (Foucault, 1980; Foucault, 1994; Foucault, 1998): power as a productive force closely tied to knowledge; a force that has the human subject as its primary product (Søndergaard, 2000; Staunæs, 2002; Kofoed, 2003; Christensen, 2013). These studies all focus on subjectification as the production of 'the appropriate student' through the micro-genetics of power: these involve mechanisms of inclusion, exclusion, positioning, and possibilities for subjectification in specific settings at school and university.

These studies show how teachers and fellow students evaluate specific students and how this process is closely tied to the selection and exclusion of 'the inappropriate student'. In the school context, students are evaluated according to academic skills and social competencies (Kofoed, 2003), how they meet expectations attached to gender and ethnicity (Kofoed, 2003; Staunæs, 2002; Buchardt, 2008; Helms \& Krøjer, 2011), and the extent to which they are able to position themselves as 'appropriate' students (Christensen, 2013). The studies also show how psychology plays a pivotal role in the evaluation of what can be regarded as 'the norm' or 'being normal' - that is, in the micro-processes of normalization. Consequently, the formation of 'the normal child' in pedagogy is achieved through an amalgam of psychology and pedagogy, which forms a power/knowledge complex in contemporary education (Rose, 1998; Walkerdine, 1998; Popkewitz, 2008; Fendler, 2001). Thus, the thesis in this article is that these analyses not only give an insight into the construction of 'normality', but may also serve as means for understanding some of the current and future insights within disability studies. In accordance with pedagogical trends in Denmark today, that is, the discourse of 'inclusion', no individual must per definition be excluded from the learning environment.

The studies of the ongoing subjectification in school contexts are 
supplemented by studies of the Danish educational discourse that includes analyses of different kinds of texts concerning education and schooling. An example can be found in Gerd Christensen's book, Individ og disciplinering det pædagogiske subjekts historie ([The individual and discipline: the history of the pedagogical subject] 2008). Through genealogical analyses of contemporary pedagogical 'trends' in Denmark (multiple intelligences, group and project studies, classroom management, learning plans, and structured education), Christensen shows how the power/knowledge complex of pedagogy-psychology works in the formation of 'the appropriate subject' for schooling: the rational agent.

'The appropriate student' of today knows how to act in a flexible school without timetabled lessons and fixed classrooms, and is even able to identify when flexibility or structure is expected (Drejer, 2012; Christensen, 2008). Many of these 'traits' can be traced back to the progressive pedagogy of the early 1900s. Thus, the expectations for 'the normal child' in current Danish education are deeply rooted in the Danish culture and concept of the child (Nørgaard, 1977; Hamre, 2012; Øland, 2007). Accordingly, they can serve as a means for understanding the discourse of the student as an individual - that is, the discourse of individualization.

One of the sources for inspiration in Danish research is a paper by Valerie Walkerdine (1998), in which she shows how psychology infiltrates the practice of school education. Influenced by Foucault, Walkerdine (1998) regards developmental psychology (mental measurement as a science) and education (mental measurement as a practice) as an important power/knowledge complex that '[...] produces the object of classification, the scientific techniques for its production and as the pedagogical techniques for its normalization and regulation' (p. 171). These two concepts define and produce 'the normal child', a process of normalization through practices of differentiation. Walkerdine's (1998) conversion of Foucault's concept of governmentality into the concept of 'developmentality' emphasizes the individualization processes further. 'Developmentality' refers to the equivalent internalization of discourse that makes individuals 'development-able' according to specific standards that are derived from psychology. This includes an idea of individual freedom and personal rationality that matures within specific developmental stages, and is expressed through the child's curiosity, creativity, learning ability, and self-initiating activity (Walkerdine, 1998, p. 190).

Lynn Fendler also applies the concept of 'developmentality' in an analysis of current pedagogical principles which focus on interactionism and at developing 'flexible' individuals (Fendler, 2001). Fendler finds the origin for this concern in the fast-changing (post-) modern labour market, where 'flexibility' connotes freedom, liberation, and de-regulation - all components that are regarded as signs of a measure of competence. However, Fendler argues that interactionism by no means frees individuals. On the contrary, it constitutes a powerful technology of the self, whose specific form of being flexible refers to being transformable and capable of participation in sociallearning processes such as groups and teams. Hence 'flexibility' and 'social skills' are not in themselves attached to freedom and liberation, but become hallmarks of normalization (Fendler, 2001; Hamre, 2012; 2014). Though these studies are conducted within the field of 'normality', they may include insights important to the field of disability studies. Hence, 'flexibility' and 'developmentability' can also be claimed to be in focus in contemporary expectations to 'the deviant subject'. As indicated, the analyses of Fendler (2001) and Walkerdine (1998) mark an intersection between the analyses of power/knowledge and 
governmentality in general education.

The tradition of governmentality studies is taken up by the Danish educational researcher John Krejsler (2002; 2004). Krejsler, informed by Thomas Popkewitz, analyses the Danish state as a contributor to the constitution of the (post-) modern individual through education. Danish law establishes different educational apparatuses as essential to current Danish education from preschool to university, and Krejsler focuses primarily on individualization as the overriding discourse in contemporary Danish education (Krejsler, 2002; 2004). As Krejsler remarks, the discourse of individualization is productive in the sense that it makes individuals believe that institutional intentions are their own goals (Krejsler, 2004). Likewise, this is an insight that could fruitfully be applied to the field of disability research. The processes of individualization that occur both within the field of 'normality' and the field of 'disability' are framed by certain institutions that all have interests in upholding certain boundaries. Thus, the policies of the subject are an active component in the construction of the individual.

To summarize, Danish and international educational research has taken up concepts of Foucault to identify some traits in the contemporary definition of 'the normal subject' in education: 'the normal subject' is constructed as autonomous, flexible, creative, socially responsive, suitable within the categories of developmental psychology, and responsible for his or her own individuality and learning as a lifelong process. He or she is capable of coworking in groups and teams and is able to master the complexity of interdisciplinarity and the flexibility of the 'transformable school'.

These desirable 'traits' may also have an impact on an analysis of the ideals and standards for 'the deviant subject' in postmodernity. As the analyses above show, contemporary expectations for 'the deviant subject' seem to meet the expectations of 'the normal subject'. Thus, development-ability, flexibility, and learnability are not only expectations for 'the normal subject' but (perhaps to a different extent) things that concern all individuals. On the other hand, the category of 'normal child' is dependent on having a constitutive 'exterior', which is included through its exclusion (Derrida, 1974). Thus, the category is both establishing and dependent on the category of 'the not-normal child', a category ready to absorb the children who do not fit into the concept of normality. Following this analysis, 'the not-normal child' lacks all the qualities (demonstrating, acting, and showing) that define 'the normal child'.

\section{Conclusion}

Looking at Foucault's contributions to the Danish field of disability studies, his early works may seem obvious when it comes to analysing internment and exclusion. However, they are inadequate when it comes to analysing newer phenomena such as individualization, individual rights, education, and inclusion. In the analysis of these issues, an equally strong influence from international Foucauldian disability research is not evident in Danish disability studies.

Foucault's influence on Danish disability studies mainly draws on works such as Discipline and Punish and Madness and civilization. According to the analysis presented in this article, one of the reasons for the impact of this influence is the close theoretical connection to the normalization discourse of the 1960s, and the historical incarceration of disabled people, which called for a strong critique of the institutionalization of that time; in line with this analysis, 
future analysis calls for a more differentiated critique of discourses such as individual rights, empowerment, and inclusion. In his work, Frank Bylov has argued for the value of education as a right for people with disabilities (Bylov, 2010), which in the current analysis has been labelled 'the pedagogical turn'.

As the analysis shows, disabled people's conditions are increasingly affected by expectations of individualization, similar to contemporary expectations of people in general. This concerns human rights, ethics, and learning. To some extent, it is even possible to say that the subject of exemption has been 'normalized'. Normalization, in this case, concerns a strong focus on individualization and inclusion. This article claims that this indicates a need for a stronger emphasis on the studies of governmentality within general education in order to analyse the dynamics of individualization as a discourse in education (Rose, 1998; Fendler, 2001; Krejsler, 2004).

Thus, when it comes to the study of the 'subject of exemption' in particular, and issues of inclusion and exclusion in general, this approach calls for a further integration of studies in general education and similar studies in special (-needs) education. In the era of postmodernity, we are all in some way 'subjects of exemption', or at least positioned as human beings with unique potentials. Within the field of disability in Denmark, this change is concerned with a discursive shift from integration to inclusion. The discourse of inclusion cannot be restricted to special-needs education, since everybody in the present school is regarded as 'special'or 'unique', which requires that the teacher and the learning environment must deal with individual learning strategies. This is in juxtaposition to the strategy of integration that regarded the individual as an exemption to the ideal of the normal in schools. In the discourse of inclusion, the problems of learning are caused by the context, rather than regarded as a personal deficit in the individual. The discourse of inclusion currently appears simultaneously with discourses of individualization, empowerment, and lifelong learning. These discourses require new analytical tools, rather than drawing on the madness-reason dichotomy.

\section{References}

Allan, J. (2005). Inclusion as an Ethical Project. In S. Tremain (Ed.) Foucault and the Government of Disability (pp. 281-297). Ann Arbor, Ml: The University of Michigan Press.

Allan, J. (2008). Rethinking Inclusive Education: The Philosophers of Difference in Practice. Dordrecht: Springer.

Baker, B. (2002). The Hunt for Disability: The New Eugenics and the Normalization of School Children. Teachers College Record, 104(4), 663-704.

Bank-Mikkelsen, N.E. (1971). Noget om åndsvage [Something about feebleminded in Treatment of deviant]. In J. Jepsen (Ed.) Afvigerbehandling [Deviation treatment] pp. 116-134København: Thaning \& Appels Forlag.

Bonfils, I. S.; Kirkebæk, B.; Olsen, L. \& Tetler, S. (Eds.) (2013). Handicapforståelser mellem teori, erfaring og virkelighed. [Interpretations of disability - between theory, experience and reality] København: Akademisk Forlag. 
Buchardt, M. (2008). Identitetspolitik i klasserummet: 'religion' og 'kultur' som viden og social klassifikation: studier $i$ et praktiseret skolefag [Identity politics in the classroom: 'religion' and 'culture' as knowledge and social classification: studies in a practiced school curriculum]. (Doctoral dissertation) Det humanistiske Fakultet, Københavns Universitet, Denmark.

Bylov, F. (2010). Den store løsladelse. En kulturhistorisk beretning om empowermentbevægelserne blandt udviklingshæmmede 1980-95. Bind I: Det kulturelle opbrud; Bind II: Front-usikkerhederne; Bind III: Afmagtens omslag til modmagt. [The great release - a cultural history of movements of empowerment and people with learning disabilities in Denmark]. Aarhus: Aarhus Universitet.

Bylov, F. (2006). Patterns of culture \& power after 'The Great Release': the history of movements of subculture \& empowerment among Danish people with learning difficulties. British Journal of Learning Disabilities 34(3), 139-145.

Christensen, G. (2008). Individ og disciplinering. Det pædagogiske subjekts historie. [The Individual and Discipline. The History of the Pedagogical Subject.] Frederiksberg: Forlaget Samfundslitteratur.

Christensen, G. (2013). Projektgrupper - en undersøgelse af subjektiveringsmekanismer i gruppe- og projektarbejdet på universitetsniveau. [Project Groups - an Analysis of Subjectification Mechanisms in Group- and Project Work at University Level] (Doctoral dissertation). Århus Universitet, Emdrup, Denmark.

Deleuze, G. (1986). Foucault. Paris: Les Éditions de Minuit.

Derrida, J. (1974). La différance. Paris: Les Édition de Minuit.

Drejer, C. (2012). Elev og Magt. En analyse af subjektiveringsstrategien af eleven, 1822-2010. [Pupil and power. An analysis of subjectification strategies, 18222010] (Doctoral dissertation). Institut for Samfund og Globalisering, Roskilde Universitet, Denmark.

Fendler, L. (2001). Educating Flexible Souls. The Construction of Subjectivity through Developmentality and Interaction. In K. Hultquist \& G. Dalberg (Eds.) Governing the Child in the New Millenium (pp. 119-142). London: Routledge.

Foucault, M. (1979). Discipline \& Punish. The birth of the Prison. New York: Vintage books, Random House.

Foucault, M. (1973). Galskapens historie [The history of madness]. Oslo: Gyldendal.

Foucault, M. (2003). Galskabens historie $i$ den klassiske periode [The history of madness in the classical era]. Frederiksberg: Det lille forlag.

Foucault, M. (1961). Folie et Déraison: Histoire de la folie à l'âge classique. Paris: Gallimard.

Foucault, M. (1965) Madness and Civilization: A History of Insanity in the Age of Reason. New York: Vintage.

Foucault, M. (1962). Maladie mentale et psychologie, Paris: PUF.

Foucault, M. (2006). Psychiatric Power, Lectures at the Collège de France 1973-1974. New York: Palgrave Macmillan.

Foucault, M. (1980). The Confession of the Flesh. Interview with M. Foucault. In C. Gordon (Ed.) Power/Knowledge Selected Interviews and Other Writings (19721977) (pp. 194-228) London and New York: Pantheon Books. 
Foucault, M. (1991) 'Governmentality'. In C. G. Burchell \& P. Miller (eds.) The Foucault effect: Studies in governmentality (pp. 87-104). Chicago. University of Chicago Press.

Foucault, M. (1998). The History of Sexuality. The Will to Knowledge. London: Penguin Books.

Foucault, M. (2005). Sindssygdom og psykologi [Mental Illness and psychology]. København: Hans Reitzels Forlag.

Foucault, M. (2001). Talens forfatning: Forelæsningsrapport: Viljen til viden: Nietzsche - genealogien, historien [The order of the discourse: The will to knowledge: Nietzsche- genealogy, and the history]. København: Hans Reitzels Forlag.

Foucault, M. (1994). The subject and power. In J. D. Faubion (ed.) Power. Essential works of Foucault 1954-1984. (Vol. 3., pp. 326-348) London: Penguin Books.

Goodley, D. \& Rapley M. (2002/2006). Changing the Subject: Postmodernity and people with 'Learning Difficulties'. In M. Corker \& T. Shakespeare (eds.) Disability/Postmodernity (pp. 127-142). London: Continuum.

Goodley, D. (2011). Disability Studies. An Interdisciplinary Introduction. London: Sage.

Hamre, B. (2014). Optimization as a dispositive in the production of differences in schools in Denmark. European Education, 45(4),7-25.

Hamre, B. (2012). Potentialitet og optimering i skolen: problemforståelser og forskelssætninger af elever - en nutidshistorisk analyse. [Potentiality and Optimization in Schooling. Labelling and Constructions of Differences]. (Doctoral dissertation). Institut for Uddannelse og Pædagogik, Aarhus University, Denmark.

Heede, D. (1992). Det tomme menneske. Introduktion til Michel Foucault [The Empty Human Being: Introduction to Michel Foucault]. København: Museum Tusculanums Forlag.

Helms, S. \& Krøjer, J. (2011). Drengeelever mellem frihed og kontrol. [Male students in between freedom and control]. Kognition \& Pædagogik, 21(82), 18-30.

Holst. J. (1977). Normalitet, pædagogik og socialpædagogik. [Normalization, education, and social education] Kandidatopgave (Dissertation) fra Danmarks Lærerhøjskole.

Holst, J. (1998). Normalitetsbegrebet i dag [The concept of normalization today]. Dansk Pædagogisk Tidsskrift, No. 6, 30-38.

Holst, J. (1993). Opbrud og normalisering. [Disruption and normalization]. Specialpædagogik, №. 3, 197-207.

Holst, J., Langager, S. \& Tetler, S. (Eds.) (2000). Specialpædagogik i en brydningstid. [Special education in a time of disruption] Århus: Systime.

Juelskjær, M. (2007). Rummenes modstand: subjektivering set i et spatielt perspektiv [The resistance of the spaces: subjectification in a spatial perspective]. In Magtballader. 14 fortællinger om magt, modstand og menneskers tilblivelse [Power ballads. 14 stories about power, resistance and the genesis of the humans] (pp. 121-141). Emdrup: Danmarks Pædagogiske Universitetsforlag.

Kirkebæk, B. (1985). Abnormbegrebet i Danmark. [The concept of the abnormal in Denmark] (Upubliceret licentiatafhandling, unpublished doctoral dissertation). Danmarks Lærerhøjskole, Denmark. 
Kirkebæk, B. (2010). Almagt og afmagt. Specialpædagogikkens holdninger, handlinger og dilemmaer. [Omnipotence and impotence. Special education - attitudes, actions and dilemmas]. København: Akademisk Forlag.

Kirkebæk, B. (2009). Behandlingen af socialt udsatte historisk set [The treatment of socially vulnerable historically]. In P. Brandt, B.L. Henriksen, K.B. Jensen \& N.C. Rasmussen (Eds.). Udsat for forståelse - en antologi om socialt udsatte [Exposed to understanding - an anthology of socially vulnerable] (pp. 42-56). København: Rådet for Socialt Udsatte.

Kirkebæk, B. (1993). Da de åndssvage blev farlige [When the feebleminded became dangerous]. Holte: Forlaget SocPol.

Kirkebæk B. (1997/1998). Defekt og deporteret. Livø-anstalten 1911-1961.[Defective and deported]. Holte: Forlaget SocPol.

Kirkebæk, B. (2004). Letfærdig og løsagtig. Kvindeanstalten Sprogø 1923-1961 [Loose and lascivious: the female institution Sprogø 1923/1961]. Holte: Forlaget SocPol.

Kirkebæk, B. (2001). Normaliseringens periode. Dansk åndssvageforsorg 1940-1970 [The period of normalization]. Holte: Forlaget SocPol.

Kirkebæk, B. (2007). Uduelig og ubrugelig. Åndssvageasylet Karens Minde 1880-1987. [Incompetent and useless. Karensminde an asylum for feebleminded, 18801987] Holte: Forlaget SocPol.

Kofoed, J. (2003). Elevpli. Inklusions-eksklusionsprocesser blandt born i skolen. [Pupil behaviour. Processes of inclusion and exclusion among children at school]. (Doctoral dissertation). Danmarks Pædagogiske Universitet, Emdrup, Denmark.

Knudsen, H. (2010). Har vi en aftale? Magt og ansvar i mødet mellem folkeskole og familie. [Do we have an agreement? Power and responsibility in the meeting between the public school and the families] Frederiksberg: Nyt fra Samfundsvidenskaberne.

Krause-Jensen, E. (1978). Viden og magt. Studier i Michel Foucaults institutionskritik [Knowledge and Power: Studies in Michael Foucault's Critique of Institutions]. Copenhagen: Rhodos.

Krejsler, J. (2002). Læring, magt og individualitet - når pædagogik iscenesættes som selvbestemmelse. [Learning, power and individuality - when pedagogy is staged as self-determination]. København: Gyldendal Uddannelse (Carpe).

Krejsler, J. (eds.) (2004). Pædagogikken og kampen om individet. [Pedagogy and the fight about the individual]. København: Hans Reitzels Forlag.

Kristensen, J-E. (2012). Viljen til inklusion - En samtidsdiagnostisk indkredsning af en ny politisk-pædagogisk dagsorden. [The will to Inclusion - A contemporary analysis of a new political-educational agenda]. Dansk Pædagogisk Tidsskrift, No. $4,50-59$.

Kristensen, J-E. \& Schmidt, L-H. (1989). Kan menneskerettighederne gøres gældende uden at være gyldige? [Can human rights be exercised without being valid?]. In J. E. Kristensen (Ed.) Menneske Rettigheder - filosofisk, juridisk, historiske, politisk. [Human Rights - philosophical, legal, historical, political] (pp. 61-82). København: Akademisk Forlag.

Masschelein, J. (2004). How to Conceive of Critical Educational Theory Today. Journal of Philosophy of Education, 38(3), 351-367.

Parker, I. (1997). Psychoanalytic Culture. London: Sage. 
Popkewitz, T. (2008). Cosmopolitanism and the Age of School Reform. New York: Routledge.

Quinn, G. \& Degener, T. (2002). Human Rights and Disability. The current use and future potential of United Nations human rights instruments in the context of disability. United Nations: New York and Geneva.

Rose, N. (1998). Inventing Our Selves. Psychology, Power and Personhood. Cambridge: Cambridge University Press.

Rydberg, L. (2006). Normaliseringen og lærerne: Lærerforeningens ageren i normaliseringens periode [The normalization and teachers: The teacher unions' actions during the normalization period] [Special issue: 'Normaliseringsideologien 50 år efter dens fremsættelse', 'Normalization ideology 50 years after its emergence']. Handicaphistorisk Tidsskrift, No. 16, 8595.

Rønn, E. M. (1996). De fattige $i$ ånden. Essays om kultur, normalitet og ufornuft. En etnologisk undersøgelse af praksis inden for dansk åndssvagevæsen og forsorg ca. 1840-1990. med eksempelmateriale fra Aandssvageanstalten Ribelund. [The poor in spirit. Essays on culture, normality and unreason. An ethnological study of practices in the Danish administration of the feebleminded and care - 1840-1990, with the material from the asylum Ribelund] .Københavns Universitet, Etnologiske studier. (Doctoral dissertation) København: Museum Tusculanums Forlag.

Slee, R. \& Cook, S. (1999). The Cultural Politics of Disability, Education and the Law. Discourse: studies in cultural politics of education. 20(2) 267-277.

Slee, R. (2011). The Irregular School: Exclusion, Schooling and Inclusive Education. London: Routledge.

Senellart, M. (2004). Om forelæsningernes kontekst [On the context of the lectures]. In: Foucault:Sikkerhed, territorium, befolkning [Security, Territory, Population].København: Hans Reitzels Forlag.

Staunæs, D. (2004). Køn, etnicitet og skoleliv. [Gender, ethnicity, and school-life]. Frederiksberg: Forlaget Samfundslitteratur.

Staunæs, D. (2012). Psy-ledelse: ledelse af/i uddannelsesorganisationer efter den affektive vending. [Psy-management: management of/in educational institutions after the affective turn]. Kvinder, Køn \& Forskning, 21(3), 62-78.

Staunæs, D., Juelskjær, M. \& Knudsen, H. (2011). Psy-Management: Drei Perspektiven auf neue Formen des (Schul-)Managements [Psy.management: three perspectives on new forms of (school) management]. In J. Metelmann \& S. Schwall (Eds.) Bildungsbürgerrecht: Schulverweigerung - Erziehungskrise Social Entrepreneurship [Educational rights: truancy, educational crisis, social entrepreneurship] (pp.109-132). Münster: Waxmann Verlag.

Søndergaard, D. M. (2000). Tegnet på kroppen. [The sign on the body]. København: Museum Tusculanums Forlag.

Tremain, S. (2005). Foucault, Governmentality, and Critical Disability Theory: An Introduction'. In S. Tremain (Ed.) Foucault and the Government of Disability. (pp. 1-24) Ann Arbor, MI: The University of Michigan Press

United Nations (1949). The Universal Declaration of Human Rights 1948. http://www.supremecourt.ge/files/upload-file/pdf/act3.pdf 
Walkerdine, V. (1998). 'Developmental psychology and the child-centred pedagogy: the insertion of Piaget into early education'. In J. Henriques, W. Hollway, C., Urwin, C. Venn \& V. Walkerdine (Eds.) Changing the Subject (pp. 153-202). London: Routledge.

Øland, T. (2007). Grænser for progressive pædagogikformer: Sociologiske undersøgelser af progressive pædagogikformer som middelklassekamp om dominans over det statslige skolegangsfelt \& praktisk-epistemologiske undersøgelser af progressiv pædagogik som ledelse af individuel frihed. [Limits of progressive pedagogy: Sociological studies of progressive pedagogy as middle class fight for dominance in the public education and practical epistemological studies of progressive pedagogy as management of individual freedom]. (Doctoral dissertation) Det humanistiske Fakultet, Københavns Universitet, Denmark. 